\title{
Chewing lice (Phthiraptera: Amblycera, Ischnocera) of some aquatic birds in Konya province, Turkey, new records for Turkish fauna
}

\author{
Bilal DİK ${ }^{1}$ Fatma HÜĞÜL ${ }^{2}$, Onur CEYLAN ${ }^{1}$ \\ ${ }^{1}$ Selçuk University, Faculty of Veterinary Medicine, Department of Parasitology; ${ }^{2}$ Institute of Health Sciences, Department of \\ Parasitology, Konya, Turkey.
}

\begin{abstract}
Summary: This study was performed to detect chewing lice species existed on some aquatic birds in Konya province in Turkey between 2014-2016. For this aim, the birds which were brought to the clinics of Selçuk University, Faculty of Veterinary Medicine for treatment, and dead birds collected at Lake Çavuşçu were examined for louse. Louse specimens collected from the birds were preserved in eppendorf tubes containing ethyl alcohol 70\%, made transparent in potassium hydroxide (KOH) $10 \%$ for 24 hours, rinsed in distilled water and transferred to alcohol $70 \%$ and $99 \%$ at consecutive days. They were mounted in Canada balsam on the slides for identification. Among studied 94 birds belonging to 12 species in eight genera in five orders, 84 of them (89.36\%) were found to be infested with lice. Eighteen louse species belonging to 14 genera were detected in the study. The genus Aquanirmus (Clay and Meinertzhagen, 1939) and the species; Aquanirmuspodicepis (Denny, 1842), Pectinopygusbifasciatus (Piaget, 1880), Anaticolamergiserrati (De Geer, 1778), Pseudomenopondolium (Rudow, 1869), Laemobothrionatrum (Nitzsch, 1818), Rallicolaminutus (Nitzsch [in Giebel], 1866), Austromenopon transversum (Denny, 1842) were reported for the first time in Turkey. Keywords: Anseriformes, Aquanirmus, Gruiformes, Podicipediformes, Pseudomenopon.
\end{abstract}

\section{Türkiye, Konya ilinde bulunan su kuşlarının çiğneyici bitleri (Phthiraptera: Amblycera, Ischnocera), Türk faunası için yeni kayıtlar}

Özet: Bu çalışma 2014-2016 yılları arasında Türkiye'de Konya ilindeki su kuşlarında bulunan çiğneyici bitleri tespit etmek amacıyla yapıldı. Bu amaçla, Selçuk Üniversitesi Veteriner Fakültesi kliniklerine tedavi için getirilen ve Çavuşçu Gölü'nden ölü olarak toplanan kuşlar bit yönünden incelendi. Kuşlardan toplanan bit örnekleri \% 70 etil alkol içeren ependorf tüplerde muhafaza edildi, 24 saat \% 10'luk potasyum hidroksitte $(\mathrm{KOH})$ saydamlaştırıldı, distile suda yıkandı ve takip eden günlerde \% 70 ve \% 99 alkole transfer edildi. Bitler Kanada balzamı ile lam üzerine yapıştırıldı ve türleri belirlendi. Beş takım, sekiz cins, 12 türe ait 94 kuş arasından 84 'ü bit ile enfeste bulundu. 14 cinse ait 18 bit türü bu çalışmada tespit edildi. Aquanirmus cinsi (Clay and Meinertzhagen, 1939) ve Aquanirmus podicepis (Denny, 1842), Pectinopygus bifasciatus (Piaget, 1880), Anaticola mergiserrati (De Geer, 1778), Pseudomenopon dolium (Rudow, 1869), Laemobothrion atrum (Nitzsch, 1818), Rallicola minutus (Nitzsch [in Giebel], 1866), Austromenopon transversum (Denny, 1842) türleri Türkiye'de ilk defa bildirildi.

Anahtar sözcükler: Anseriformes, Aquanirmus, Gruiformes, Podicipediformes, Pseudomenopon.

\section{Introduction}

Around 10,500 bird species have been detected in the world (30), while the number for Turkey is 482 bird species (39). Until a decade ago, 3910 out of 5642 described lice species had been approved as valid species. Among them, 2737 and 1173 species are belonging to Ischnocera and Amblycera suborders, respectively (37). Chewing lice cause irritation, allergic reactions in the hosts, stomatitis in white pelicans (14), decreasing in animal products and they can transmit some filarial diseases such as Pelecitus fulicaeatrae (Diesing, 1861) (5) and Sarconema eurycerca (35), additionally typhus, cholera and rickettsial diseases (38).

Aquatic birds exist in the orders Anseriformes, Gaviiformes, Procellariiformes, Podicipediformes,
Phoenicopteriformes, Pelecaniformes, Suliformes, Gruiformes and Charadriiformes in Turkey. There are more than 160 aquatic birds species belonging to the orders in Turkey, but nearly 50 species were examined for chewing lice and 60 lice species have been detected yet. There is some information about chewing lice on aquatic birds in Turkey. Several studies have been performed concerning about this topic; they are usually case reports or new records for the country, some of them in relatively large scales were performed on chewing lice species on some aquatic birds in different regions of Turkey, and several lice species were reported $(15,16,17,18,19,20$, $21,22)$. There are no studies on chewing lice species found on birds in the orders Gaviiformes and Procellariiformes, but there is one study on the birds in orders of 
Podicipediformes and Suliformes (33). As a result of the published studies, some information has been obtained with regard to the lice fauna found on aquatic birds in Turkey. However, our knowledge is insufficient and we need to perform much more studies on louse fauna on the birds in Turkey. This study was performed to detect chewing lice species existing on aquatic birds in Konya province in Turkey.

\section{Materials and Methods}

This study was carried out on some aquatic birds in Konya province in Turkey between 2014-2016. The injured birds, which were brought to the clinics of Veterinary Faculty, Selçuk University for treatment and birds which were collected as dead from Lake Çavuşçu were examined for louse. Ninety-four birds belonging to 12 bird species in 8 genera in 5 orders were examined in the study (Table 1). The feathers of each live bird were carefully examined and lice were removed with forceps. After visual examination, a synthetic phyretroids insecticide were applied to birds placed in a white basin or carton boxes and were kept at least 15-20 minutes. According to Clayton and Walther (13), the birds found dead in the lake were washed under tap water in a nylon bag and examined macroscopically. The louse specimens collected from the birds were preserved in eppendorf tubes in $70 \%$ ethanol. They were cleared in potassium hydroxide (KOH) $10 \%$ for 24 hours, rinsed within distilled water and passed in alcoholseries $70 \%$ and $99 \%$ at two consecutive days. They were mounted in Canada balsam on the slides and kept for drying in an incubator at $50{ }^{\circ} \mathrm{C}$ for a few weeks. Lice species were examined under light microscope and were identified by using the relevant literatures $(9,10,11,12,26,27)$.

\section{Results}

In this study, 94 bird samples of 12 species in eight genera belonging to the five orders were examined for louse, and $84(89.36 \%)$ of them were found to be infested by the lice, 18 lice species; 12 Ischnoceran species in the nine genera and six Amblyceran species in the five genera were identified (Table 1). Infestation rate was $100 \%$ for Gruiformes and Charadriiformes, $98 \%$ for Podicipediformes, 80\% for Pelecaniformes, and 53\% for Anseriformes (Graphic 1). While Aquanirmus podicepis (Denny, 1842) in 21 birds and Pseudomenopon dolium (Rudow, 1869) in three birds were determined as one species, they were detected together with in 30 Podiceps cristatus.

Table 1. Studied birds and chewing lice species found on the birds. Tablo 1. Çalışılan kuşlar ve bu kuşlar üzerinde bulunan çiğneyici bit türleri.

\begin{tabular}{|c|c|c|c|c|c|}
\hline Bird order & Bird family & Bird name & $\begin{array}{l}\text { Bird number } \\
\text { examined }(n)\end{array}$ & $\begin{array}{l}\text { Bird number } \\
\text { infested (n) }\end{array}$ & Louse species \\
\hline \multirow{2}{*}{ Pelecaniformes } & \multirow{2}{*}{ Pelecanidae } & Pelecanus onocrotalus & 4 & 3 & $\begin{array}{l}\text { Pectinopygus forficulatus } \\
\text { Piagetiella titan }\end{array}$ \\
\hline & & Pelecanus crispus & 1 & 1 & $\begin{array}{l}\text { Pectinopygus bifasciatus } \\
\text { Piagetiella titan }\end{array}$ \\
\hline \multirow{6}{*}{ Anseriformes } & \multirow{6}{*}{ Anatidae } & Anser anser & 2 & - & - \\
\hline & & Anas crecca & 5 & 3 & $\begin{array}{l}\text { Anatoecus dentatus } \\
\text { Anatoecus icterodes } \\
\text { Trinoton querquedulae }\end{array}$ \\
\hline & & Anas acuta & 1 & 1 & Trinoton querquedulae \\
\hline & & Anas strepera & 2 & 1 & Anaticola $\operatorname{sp~N}$ \\
\hline & & Aythya ferina & 6 & 3 & $\begin{array}{l}\text { Anaticola mergiserrati } \\
\text { Anatoecus icterodes }\end{array}$ \\
\hline & & Aythya fuligula & 1 & 1 & Trinoton querquedulae \\
\hline Charadriiformes & Lariidae & $\begin{array}{l}\text { Ichthyaetus } \\
\text { melanocephalus }\end{array}$ & 1 & 1 & $\begin{array}{l}\text { Austromenopon transversum } \\
\text { Quadraceps punctatus } \\
\text { Saemundssonia lari }\end{array}$ \\
\hline Podicipediformes & Podicipedidae & Podiceps cristatus & 55 & 54 & $\begin{array}{l}\text { Aquanirmus podicepis } \\
\text { Pseudomenopon dolium }\end{array}$ \\
\hline \multirow[t]{2}{*}{ Gruiformes } & \multirow[t]{2}{*}{ Rallidae } & Fulica atra & 14 & 14 & $\begin{array}{l}\text { Fulicoffula lurida } \\
\text { Incidifrons fulicae } \\
\text { Laemobothrion atrum } \\
\text { Pseudomenopon pilosum } \\
\text { Rallicola fulicae }\end{array}$ \\
\hline & & Gallinula chloropus & 2 & 2 & $\begin{array}{l}\text { Rallicola minutus } \\
\text { Pseudomenopon pilosum }\end{array}$ \\
\hline Total & & & 94 & 84 & \\
\hline
\end{tabular}




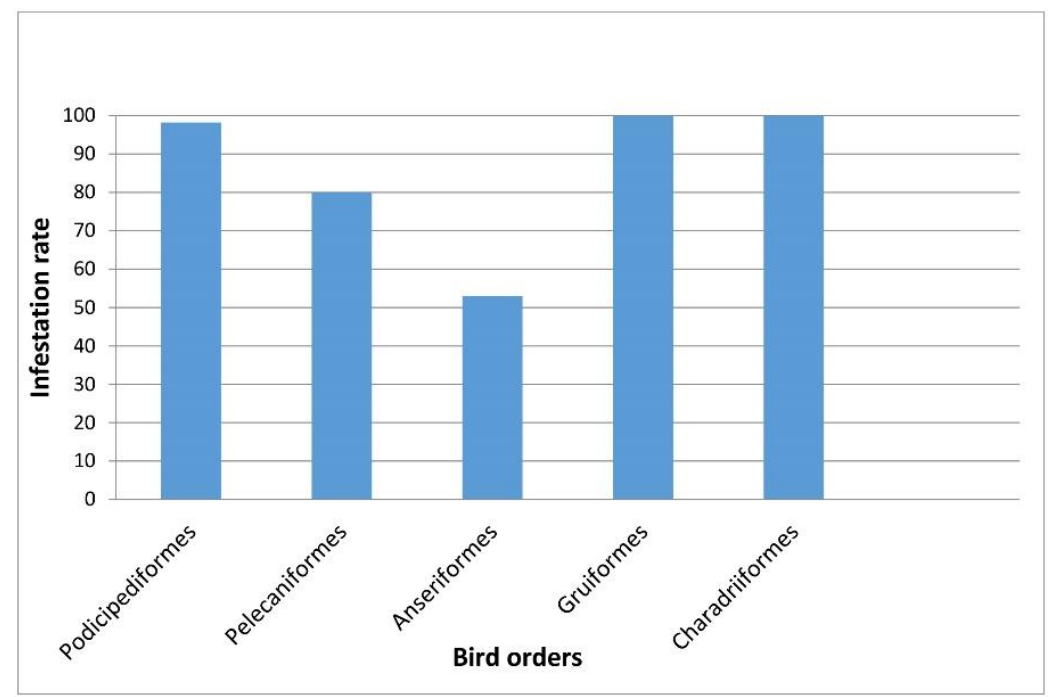

Graphic 1. Infestation rates of chewing lice to the bird orders.

Grafik 1. Kuş takımlarına göre çiğneyici bit enfestasyon oranları.

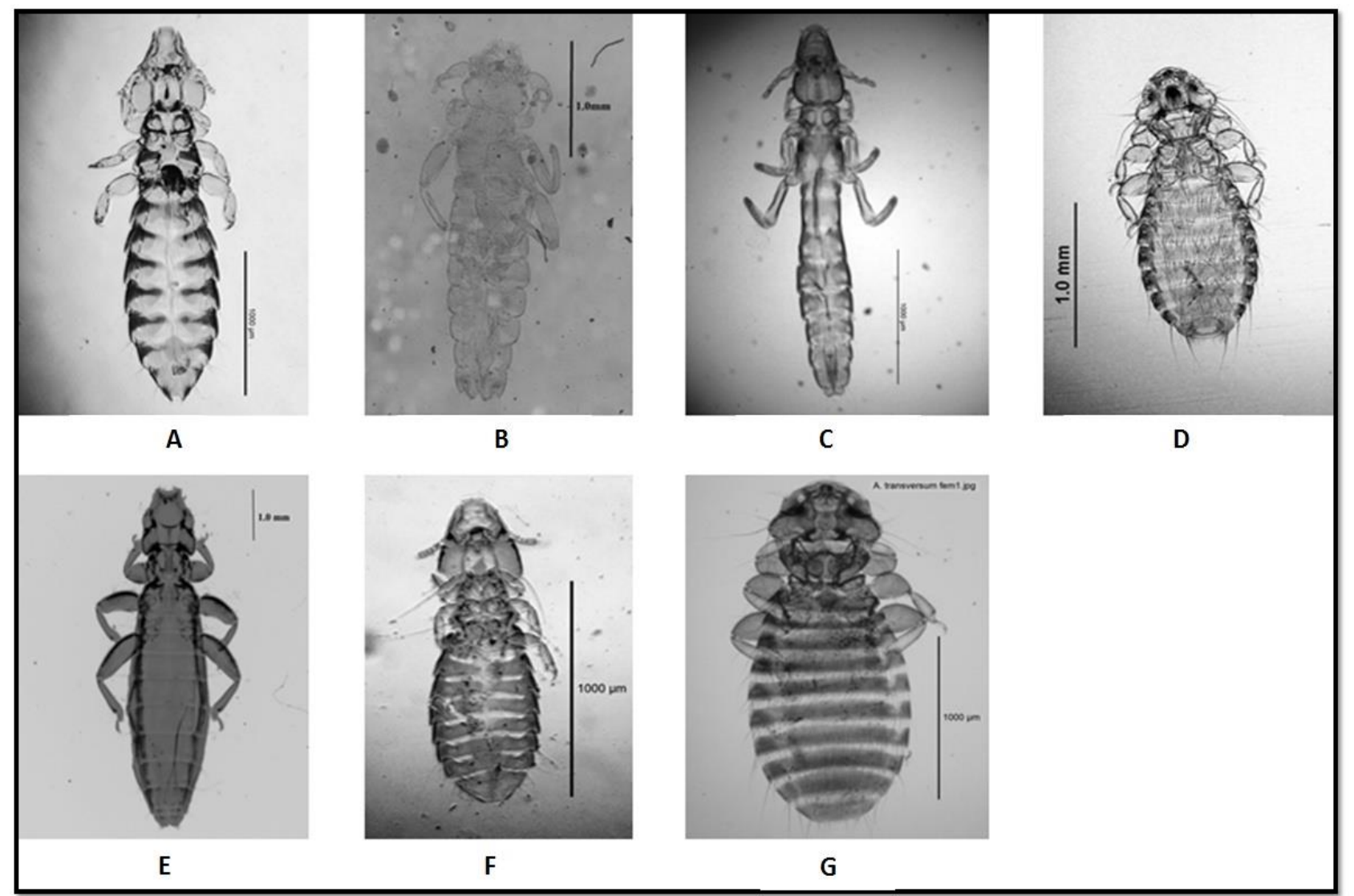

Figure 1. Photos of some lice species identified in the study, original. A. Aquanirmus podicepis, female. B. Pectinopygus bifasciatus, male. C. Anaticola mergiserrati, male. D. Pseudomenopon dolium, female. E. Laemobothrion atrum, male. F. Rallicola minutus, female. G. Austromenopon transversum, female.

Şekil 1. Çalışmada tespit edilen bazı bit türlerinin resimleri, orijinal.

A. Aquanirmus podicepis, dişi. B. Pectinopygus bifasciatus, erkek. C. Anaticola mergiserrati, erkek. D. Pseudomenopon dolium, dişi. E. Laemobothrion atrum, dişi. F. Rallicola minutus, dişi. G. Austromenopon transversum, dişi.

The genus Aquanirmus Clay and Meinertzhagen, 1939; and the species Aquanirmus podicepis (Denny, 1842) (Figure 1A), Pectinopygus bifasciatus (Piaget, 1880) (Figure 1B), Anaticola mergiserrati (De Geer, 1778) (Figure 1C), Pseudomenopon dolium (Rudow,
1869) (Figure 1D), Laemobothrion atrum (Nitzsch, 1818) (Figure 1E), Rallicola minutus (Nitzsch [in Giebel], 1866) (Figure 1F) and Austromenopon transversum (Denny, 1842) (Figure 1G) were reported for the first time in Turkey. 


\section{Discussion and Conclusion}

In spite of increased number of investigations about louse fauna of bird species in Turkey, investigated bird and reported louse species numbers are still insufficient. Approximately, 250 bird species, half of the Turkish bird fauna known, have been examined for lice and no lice were found on some of them. According to the published studies about chewing lice species found on the birds in Turkey up today, about 150 chewing lice species have been identified.

There are 160 aquatic bird species in Turkey, and approximately $1 / 3$ of them were examined for louse, and 60 lice species have been detected yet. In these studies, 25 chewing lice species in Charadriiformes, 11 in Gruiformes, 10 in Anseriformes, eight in Pelecaniformes, four in Phoenicopteriformes, two in Suliformes have been detected. In this study, 94 bird species in the five orders examined for chewing lice, and 84 of them were found to be infested with lice.

There is a study on chewing lice on the birds in the order Podicipediformes in Turkey; one Tachybaptus ruficollis sample examined in that study, however no lice detected on the bird (2). In this study, the bird number in the order Podicipediformes composed the biggest sample between the all bird orders examined in the study, 55 individuals in this order were examined, and 54 (98\%) of them were infested with lice. Therefore, P. cristatus in this order was examined for the lice for the first time in Turkey, and two lice species; Aquanirmus podicepis and Pseudomenopon dolium were detected for the first time in the country, as well.

Piagetiella titan, Pectinopygusforficulatus and Colpocephalumeucarenum have been recorded on great white pelican previously in Turkey $(14,15,16,24)$. According to the findings of the studies; $P$. titan and $P$. forficulatus were the most common lice species on great white pelican, but $C$. eucarenum was found rarely on the pelicans. Two great white pelican specimens were examined in this study, and both were infested by $P$. titan and $P$. forficulatus, as C.eucarenum was detected on one pelican. Piagetiella titan and P. forficulatus were detected as common species and collected in huge numbers, while only two male $C$. eucarenum were obtained. These findings are similar to the results of the previous studies. Dik (14) reported that $P$. titan can cause erosive stomatitis in white pelican, although it was not detected on the pelicans infested by $P$. titan in the study. Additionally, a dalmatian pelican was examined in the study and it was found infested with Pectinopygus bifasciatus. Therefore, $P$. bifasciatus was reported for the first time in Turkey.

Several chewing lice species belonging to the genera Anatoecus, Anaticola, Trinoton, Holomenopon were reported from Anseriformes in the world (6, 7, 8, 29). In the previous studies carried out on chewing lice species found on Anseriformes in Turkey, Anatoecus dentatus (Scopoli, 1763) and Anaticola crassicornis (Scopoli, 1763) on domestic ducks, Anaticola anseris (Linnaeus, $1758)$ on domestic geese $(3,34)$, Trinoton anserinum (Fabricius [J.C.], 1805) on Mute Swan (Cygnus olor) (1) and whooper swan (Cygnus cygnus) (35), Anatoecus icterodes (Nitzsch, 1818) on summer duck (Marmaronetta angustirostris) (19) and Anaticola crassicornis, Holomenopon sp. and Trinoton querquedulae (Linnaeus, 1758) on northern pintail (Anas acuta) (21) were detected. In a study was conducted to detect louse species parasitizing ducks at Lake Akşehir, Konya between 20102011, 54 ducks, which belonged to seven species; teal, garganey, shoveler, northern pintail, mallard, ruddy shelduck, common shelduck were examined and 29 $(53.70 \%)$ out of them were found to have been infested with lice (20). In total, eight louse species; Anatoecus regina Ansari, 1955, Anaticola magnificus Ansari, 1955, Holomenopon tadornae (Gervais, 1844), A. crassicornis, A. dentatus, A. icterodes, T. querquedulae, Holomenopon clypeilargum Eichler, 1943 were reported in the study (23). In this study, 17 bird samples belonging to the genera Anser, Anas and Aythya were examined, nine of them were found to be infested and four lice species were identified. Aythya ferina and A. fuligula were examined for the first time in the study in Turkey; four of seven birds in these species were infested by the lice; A. icterodes, A. mergiserrati and T. querquedulae. Thus, A. mergiserrati was reported for the first time in Turkey.

There are 12 bird species in the order Gruiformes in Turkey, 6 of them were examined for chewing lice and 11 lice species, five on common coot were reported in previously (21, 22, 25). Four lice species; Fulicoffula lurida (Nitzsch, 1818), Incidifrons fulicae (Linnaeus, 1758), Pseudomenopon pilosum (Scopoli, 1763), and Rallicola fulicae (Denny, 1842) were detected on common coot (22), but no louse detected on common moorhen (25). In this study, all of these species given above were detected extensively except $I$. fulicae which is rarely on the common coot. In addition to these species, L. atrum was collected in less number on five common coot for the first time in Turkey.

Charadriiformes is the second largest bird order after Passeriformes in Turkey and there are approximately 90 bird species (39). There are some studies performed on the lice species on charadriiform birds in Turkey $(18,21,22$, $25,31,32,36$ ). Eighteen of 90 birds species in the order Charadriiformes in Turkey were examined for chewing lice up to date, and 25 lice species were detected in these studies $(20,22,25,31,32)$. Although, few bird species and samples were studied in those studies. There is only one study carried out on chewing lice for the birds in the order, and in this study, 41 bird samples belonging to the genera Scolopacidae and Sternidae were examined for lice, 31 of 
them were found to be infested with lice and 20 lice species detected (20). At the end of these studies, 25 lice species were reported from charadriiform birds in Turkey up to day. Only one bird species (I. melanocephalus) was examined and three lice species; A. transversum, $Q$. punctatus and $S$. lari were identified. The last two lice species were previously recorded from the birds in Turkey. However, A. transversumhas been reported for the first time in Turkey in the study.

It was reported that, $P$. pilosum has been a vector of Pelecitus fulicaeatrae (Nematoda: Onchocercidae), a common filarioid nematode parasite in American coot (Fulica americana) (5). Although, American coot does not live in Turkey, common coot is very common in Turkey and this nematode had also been recorded from common coot (4). According to Escudero et al (28), P. fulicaeatrae was reported from birds in several families, such as Podicipedidae, Ardeidae, Anatidae, Accipitridae, Pandionidae, Rallidae, Laridae, and Coraciidae. $P$. pilosum was detected in almost all common coots in this study. Probably, this can be a risk factor for transmission of $P$. fulicaeatrae to common coot and the other birds in the country, but there is no study on this topic in Turkey. On the other hand, S. eurycerca is a filarioid nematode known as heartworm of swans and geese, and $T$. anserinum is a vector of this nematode, and this nematode was reported from Whooper swan in Turkey (35). Neither T. anserinum nor other chewing lice reported from geese was detected, as well as any Whooper swan was examined in the study.

As a result, 94 bird specimens in the five orders were examined in this study, and $84(89.36 \%)$ of them were infested with chewing lice. P. cristatus, A. ferina and A. fuligula were examined for louse for the first time in the study in Turkey. The genus Aquanirmus and the species A. podicepis, $P$. bifasciatus, A. mergiserrati, P. dolium, $L$. atrum, $R$. minutus and A. transversum were reported for the first time in Turkey.

In spite of these findings on the lice species, further investigations are needed, not only to complete the list of Phthiraptera fauna in Turkey, but also to provide information about phylogenetic relation among species and parasite-host vector relationships.

\section{References}

1. Açıcı M, Umur Ş, Gürsoy A (2005): Yabanıl bir kuğuda Trinoton anserinum olgusu. XIV. Ulusal Parazitoloji Kongresi, 18-25 Eylül 2005, İzmir, pp. 225-226.

2. Açıcı M, Adam C, Gürler AT, et al. (2011): Chewing lice (Phthiraptera; Amblycera, Ischnocera) from some wild birds in the Kizllirmak Delta (Turkey). Trav Mus Hist Nat "Grigore Antipa", 54, 395-407.

3. Aksin N (2004): Elazlğ yöresinde yabani kazlarda bit enfestasyonu. Turk J Vet Anim Sci, 28, 87-90.
4. Bartlett CM, Greener EC (1986): A revision of Pelecitus Railliet and Henry, 1910 (Filarioidea, Dirofilariinae) and evidence for the " capture " by mammals of filarioids from birds. Bull Mus Natl Hist Nat, 4 e sér., 8, section A, 8, 47-99.

5. Bartlett CM, Anderson RC (1989): Some observations on Pseudomenopon pilosum (Amblycera: Menoponidae), the louse vector of Pelecitus fulicaeatrae (Nematoda: Filarioidea) of coots, Fulica americana (Aves: Gruiformes). Can J Zool, 67, 1328-1331.

6. Broderson D, Canaris AG, Bristol JR (1977): Parasites of waterfowl from Southwest Texas: II. The Shoveler, Anas clypeata. J Wildlife Disease, 13, 435-439.

7. Buscher HN (1965): Ectoparasites from Anseriform birds in Manitoba. Can J Zool, 43, 219-221.

8. Canaris AG,Mena AC, Bristol JR (1981): Parasites of waterfowl from Southwest Texas: III. The Green-winged Teal, Anas crecca. J Wildlife Disease, 17, 57-64.

9. Castro D del C, Cicchino AC (1983): Contribucion al conocimiento de los Malofagos Argentinos XIII. Dos nuevas especies del genero Incidifrons Ewing, 1929 (Mallophaga: Philopteridae) parasitas del genero Fulica (AvesGruiformes) de Argentina. Rev Soc Entomol Argentina, 42, 273-281.

10. Clay T (1953): Revisions of the genera of Mallophaga. I. The Rallicola-complex. Proc Zool Soc Lond, 123, 563-587.

11. Clay T (1961): Three new species of Mallophaga (Insecta). Bull Brit Mus Nat Hist (Ent), 11, 43-58.

12. Clay T (1969): A key to the genera of the Menoponidae (Amblycera: Mallophaga: Insecta). Bull Brit Mus Nat Hist (Ent), 24, 1-26.

13. Clayton DH, Walther BA (1997): Collection and quantification of arthropod parasites of birds. 419-440. In: DHClayton, J Moore (Eds), Host-Parasite Evolution: General Principles and Avian Models. Oxford Univ Press, England.

14. Dik B (2006): Erosive stomatitis in a white pelican (Pelecanusonocrotalus) caused by Piagetiella titan (Mallophaga: Menoponidae). J Vet Med B, 53, 153-154.

15. Dik B, Uslu U (2006): The first recording of Piagetiella titan (Menoponidae: Mallophaga) on a white pelican (Pelecanusonocrotalus, Linneaus) in Turkey. Türkiye Parazitol Derg, 30, 128-131.

16. Dik B, Uslu U (2008): Türkiye'de beyaz pelikanlarda (Pelecanus onocrotalus, Linneaus) görülen Mallophaga türleri. Türkiye Parazitol Derg, 32, 71-76.

17. Dik B, Uslu U (2009): Konya hayvanat bahçesindeki kanatlı hayvanlarda görülen çiğneyici bit (Phthiraptera: Amblycera, Ischnocera) türleri. Türkiye Parazitol Derg, 33, 43-49.

18. Dik B (2010): Türkiye'de evcil ve yabani kanatllarda görülen bit türleri. Türkiye Parazitol Derg, 34, 55-60.

19. Dik B (2010): New records of chewing lice (Phthiraptera) from some bird species in Turkey. Türkiye Parazitol Derg, 34, 168-173.

20. Dik B, Şekercioglu ÇH, Kirpik MA, et al. (2010): Chewing lice (Phthiraptera) species found on Turkish shore birds (Charadriiformes). Kafkas Üniv Vet Fak Derg, 16, 867-874.

21. Dik B, Şekercioğlu CH, Kirpik MA (2011): Chewing lice (Phthiraptera) species found on birds along the Aras river, Iğdır, Eastern Turkey. Kafkas Üniv Vet Fak Derg, 17, 567573. 
22. Dik B, Yamaç E, Uslu U (2011): Chewing lice (Phthiraptera) found on wild birds in Turkey. Kafkas Üniv Vet Fak Derg, 17, 787-794.

23. Dik B, Uslu U (2012): Studies on chewing lice (Phthiraptera) species found on some duck (Anseriformes: Anatidae) species at lake Akşehir, Turkey. Kafkas Univ Vet Fak Derg, 18, 1055-1060.

24. Dik B, Yamaç E, Uslu U (2013): Studies on chewing lice (Phthiraptera: Amblycera, Ischnocera) species from domestic and wild birds in Turkey. Kafkas Üniv Vet Fak Derg, 19, 553-560.

25. Dik B, Per E, Erciyas-Yavuz K, et al. (2015): Chewing lice (Phthiraptera: Amblycera, Ischnocera) species found on some birds in Turkey, with new records and new host. Turkish J Zool, 39, 790-798.

26. Edwards RL (1965): Revision of the Genus Aquanirmus (Mallophaga: Philopteridae), parasitic on Grebes (Podicipedidae). Can Entomol, 97, 920-935.

27. Emerson KC (1955): A review of the genus Rallicola (Philopteridae: Mallophaga) found on Aramidae, Psophiidae, Rallidae. Ann Entomol Soc Am, 48, 284-299.

28. Escudero G, Diaz JI, Notarnicola J (2007): New host and distribution records of Pelecitus fulicaeatrae (Diesing, 1861) (Nematoda, Onchocercidae). Acta Parasitol, 52, 419421.

29. Garbarino VR, Campbell JV, O'Brien J, et al. (2013): Phthiraptera and Acari collected from 13 species of Waterfowl from Alabama and Georgia. Southeastern Naturalist, 12, 413-426.

30. Gill F, Donsker D (2016): IOC World Bird List (v5.1). Available at http://www.worldbirdnames.org. (Accessed 25 January 2016)

31. Girişgin AO, Dik B, Girişgin O (2013): Chewing lice (Phthiraptera) species of wild birds in northwestern Turkey, with a new host record. Int J Parasitol Parasites Wildl, 2, 217-221.

32. Göz Y, Dik B, Orunç-Kılınç Ö, et al. (2015): Chewing lice (Phthiraptera: Amblycera, Ischnocera) on several species of wild birds around the lake Van Basin, Van, eastern Turkey. Kafkas Univ Vet Fak Derg, 21, 333-338.
33. Karatepe M, Dik B, Karatepe B (2016): Chewing lice species (Phthiraptera) found on a European shag (Phalacrocorax aristotelis) in Turkey. New records of a genus and two species for the Turkish Phthiraptera Fauna. Turk Zool Derg (Accepted).

34. Merdivenci A (1965): Türkiye'nin Entomolojik Coğrafyast. 114-152.In: EK Unat, Ş Yaşarol, A Merdivenci (Ed), Türkiye'nin Parazitolojik Coğrafyası. Ege Üniversitesi Matbaası, İzmir.

35. Oğuz B, Orunç Kılınç Ö, Değer MS (2015): First reports of Sarconemaeurycerca and Trinotonanserinumin the Whooper Swan (Cygnus cygnus) in Van, Turkey. Kafkas Univ Vet Fak Derg, 21, 933-936.

36. Orunç-Kılıç Ö, Biçek K, Özdal N, et al. (2013): Van gölü çevresinde yaşayan martılarda (Larusmichahellis, Naumann 1840) bulunan çiğneyici bit (Phthiraptera) türleri. YYU Vet Fak Derg, 24, 117-121.

37. Price RD, Hellenthal RA, Palma RL, et al. (2003): The chewing lice: World checklist and biological overview. Illinois Natural History Survey Special Publication, 24. x + $501 \mathrm{pp}$.

38. Seegar WS, Schiller EL, Sladen WJL, et al. (1976): $A$ mallophaga, Trinoton anserinum, as a cyclodevelopmental vector for a heartworm parasite of waterfowl. Science, 194, 739-740.

39. Trakus (2016): Turkey's anonymous birds. Available at http://www.trakus.org. (Accessed 18 April 2016).

Geliş tarihi: 25.05.2016 / Kabul tarihi: 25.01.2017
Address for correspondence:
Prof. Dr. Bilal DiK
Selçuk University,
Faculty of Veterinary Medicine,
Department of Parasitology,
42250 Selçuklu, Konya, Turkey.
e-mail:bdik2005@yahoo.com 